\title{
On the integration of the methods of forming and research of images of objects against the background of noises and interference
}

\author{
Nguyen Minh Tuong, \\ Viktor I. Nefedov ${ }^{\circledR}$, \\ Nikolay S. Chekalkin, \\ Igor V. Kozlovsky, \\ Aleksey V. Malafeev, \\ Natalia A. Mirolyubova, \\ Maksim A. Nazarenko
}

МИРЭА - Российский технологический университет, Москва 119454, Россия

${ }^{\circledR}$ Автор для переписки, е-таil: nefedov@mirea.ru

This article discusses the application of complex methods for detecting, recognizing, distinguishing borders and measuring various parameters of noisy, low-contrast, difficult-to-see images of space, air or ground objects. The problem of detecting, recognizing, distinguishing and measuring parameters of objects images (space or air objects, aircraft, ship, ground transport, people, coasts, etc.) is still among the very complex, completely unsolved radio engineering and telecommunications ("connected") tasks. Currently, infrared (IR) direction finding, optical (laser location) direction finding and radar are used to detect, recognize, distinguish boundaries and measure the parameters of unknown objects against the background of external natural or artificial interference and noise. These methods have their own advantages and disadvantages, which do not always coincide. Therefore, it is of theoretical and practical interest to use them jointly, multifunctionally, or integrationally to identify objects against the background of external natural or deliberate interference and noise. When applying multifunctional methods for detecting, recognizing, distinguishing borders and measuring parameters of noisy, low-contrast images of objects against the background of external natural or artificial interference and noise. Digital processing of objects is mainly used now, which can be defined as a process during which an image is: modified to obtain a new one, which will be more convenient for research by a computer, or by the human eye; it is transformed into a certain set of characteristics and parameters visible and related to the observation area that are automatically analyzed by the computer, or directly presented to a person, taking into account pre-established criteria for developing a final conclusion about the studied object. Typically, the result of digital processing of the received signals is a new image that can be easily converted to analog form and directly observed on a computer display. 
On the integration of the methods of forming and research of images of objects against the background of noises and interference

Keywords: detection, recognition, measurement, transformation, objects, images, infrared direction finding, radar, optical (laser) location, resolution, radio signal.

For citation: Nguyen M.T., Nefedov V.I., Chekalkin N.S., Kozlovsky I.V., Malafeev A.V., Mirolyubova N.A., Nazarenko M.A. On the integration of the methods of forming and research of images of objects against the background of noises and interference. Rossiiskii tekhnologicheskii zhurnal = Russian Technological Journal. 2020;8(2)33-42 (in Russ.). https://doi.org/10.32362/2500-316X-2020-8-2-33-42

\section{Об интеграции методов формирования и исследования изображений объектов на фоне шумов и помех}

М.T. Нгуен,

В.И. Нефедов ${ }^{\circledR}$,

Н.С. Чекалкин,

И.В. Козловский,

А.В. Малафеев,

Н.А. Миролюбова,

М.А. Назаренко

MIREA - Russian Technological University, Moscow 119454, Russia

${ }^{\circledR}$ Corresponding author, e-mail: nefedov@mirea.ru

В статье рассматривается применение интегрированных методов обнаружения, распознавания, выделения границ и измерения различных параметров зашумленных, слабоконтрастных, сложноразличимых изображений космических, воздушных или наземных объектов. Проблема обнаружения, распознавания, выделения и измерения параметров изображений объектов (космический или воздушный объекты, самолет, корабль, наземный транспорт, человек, побережье и пр.) до сих пор относится к числу весьма сложных, до конца нерешенных радиотехнических и телекоммуникационных (связных) задач. В настоящее время для обнаружения, распознавания, выделения границ и измерения параметров неизвестных объектов на фоне внешних естественных помех и шумов применяют инфракрасную, или ИК-пеленгацию, оптическую (лазерную) локацию, пеленгацию и радиолокацию. Данным методам присущи свои достоинства и недостатки, не всегда совпадающие. Поэтому представляет теоретический и практический интерес совместного, многофункционального, или комплексированного их использования для выявления объектов. При этом сейчас применяют цифровую обработку объектов, которую можно определить как процесс, в течение которого изображение или модифицируется, для получения нового, которое будет более удобным для исследования компьютером, или глазом человека, или преобразуется в определенную совокупность видимых и связанных с областью наблюдения характеристик и параметров, анализируемых компьютером автоматически, или непосредственно представляемых человеку, с учетом предварительно установленных критериев для выработки окончательного заключения об исследуемом объекте. Как правило, результатом цифровой обработки полученных сигналов является новое изображение, которое можно легко преобразовать и непосредственно наблюдать на дисплее компьютера. 
Ключевые слова: обнаружение, распознавание, измерение, преобразование, объекты, изображения, ИК-пеленгация, радиолокация, оптическая (лазерная) локация, разрешающая способность, радиотехнический сигнал.

Для цитирования: Нгуен М.Т., Нефедов В.И., Чекалкин Н.С., Козловский И.В., Малафеев А.В., Миролюбова Н.А., Назаренко М.А. Об интеграции методов формирования и исследования изображений объектов на фоне шумов и помех. Rossiiskii tekhnologicheskii zhurnal = Russian Technological Journal. 2020;8(2):33-42 (in Russ.). https://doi.org/10.32362/2500-316X-2020-8-2-33-42

\section{Problems and methods of detection, recognition and measuring parameters of objects}

The aim of this work is to review complex methods that allow us to improve the estimation of image parameters of various objects against the background of external natural interference and noise, which for one reason or another is difficult to calculate using simple methods.

The problem of determining the parameters of low-contrast images of objects (space or air objects, an airplane, a ship, ground transport, etc.) against the background of external natural or deliberate interference and noise has always been and remains a problem in science and technology, and so far it is one of the most complex unsolved problems, especially with the required high probability of correct detection; recognition and application tools of counteracting their detection and recognition of distorted images. A series of images formed by the IRD (infra-red detection), optical camera and RLS of side view is shown in Fig. 1 [1-5].

At present, infrared direction finding (thermal imaging - or TPS systems), laser (optical) location (OL), [2] and radiolocating (RL) are used to form, detect, recognize, identify borders and measure various parameters of noisy, low-contrast images, space and ground objects.
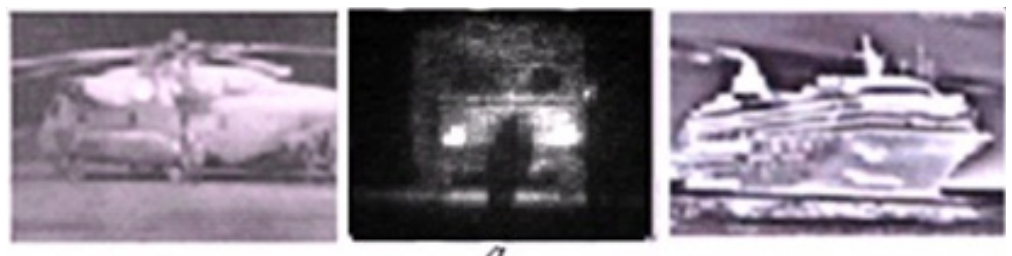

a

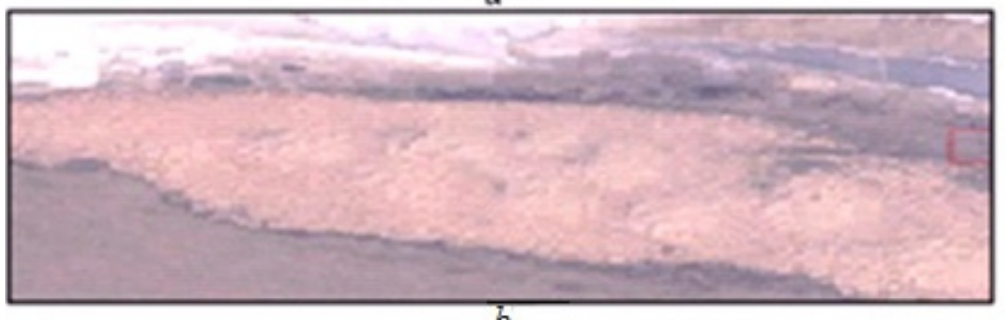

b

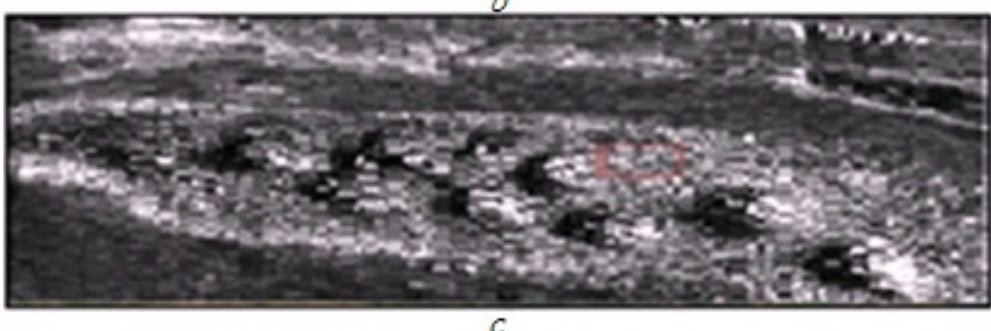

Fig. 1. Images of objects:

$\boldsymbol{a}$ - infrared direction finding; $\boldsymbol{b}$ (bay) - laser-optical and $\boldsymbol{c}$ - radiolocating. 
For specialists, their use in a complex (combinational) method of processing distorted images of objects against the background of external natural and artificial interference and noise is of practical interest.

IR direction finding. IR direction finding can be considered as a special case of thermal imaging and radiothermal location shooting, although there are differences between them. Information from an IR camera has, as a rule, an image form similar to a television one, but is examined against the background of internal, external natural or artificial interference and interference.

Recently, the problem of finding and introducing new automated digital methods for processing thermal (thermographic) images becomes more and more urgent. Such images are obtained by radar mapping, analyzing images of flying rockets, helicopters, airplanes, drones, quadcopters, studying the thermal insulation properties of space shuttles, etc.

Processing the parameters of the distorted IR image against the background of external natural or artificial interference and noise is a very difficult task nowadays. A lot of ready-made solutions from the processing distorted images in space, aviation, medical, radio astronomy areas and in thermal monitoring control systems are not widely used. This is due to a number of specific features typical for distorted IR images obtained against the background of external natural or artificial interference and noise.

This raises a number of specific problems inherent in IR images. These include [5]:

- the low contrast of individual parts of objects of distorted IR images;

- the poor spatial resolution of the details of objects;

- the presence of geometric and spatial distortions;

- the non-stationary process of information saturation for different fields of a distorted image;

- the presence of multiplicative noise and interference (multiplied by the signal).

Moreover, information about the parameters of objects in distorted IR images has a statistical, probabilistic nature. This makes it difficult to process various parameters of IR objects. Therefore, when analyzing distorted IR images and, in particular, when recognizing the selection of objects, one has to use statistical methods for processing them.

Important advantages of IRDs used for the formation and processing of images are stealth, high resolution in angular coordinates, the ability to detect and fairly accurately recognize heated objects.

The disadvantages include a strong dependence on weather conditions and the difficulty of detecting objects at their low temperature. A drawback of IRD is also the fundamental impossibility of range resolution by one system, which makes it difficult to measure the parameters of objects located in the same angular direction. To resolve objects in range it is necessary to use at least two IRDs spaced in azimuth.

The infrared direction finding also includes radiothermal direction finding (RTD) (a type of thermal imaging or passive radar) - the detection and location of various objects by their own thermal radiation [6]. RTDs are most often used in military areas and security systems for detecting radiothermal contrasting space, air and ground targets and homing weapons, in navigation, etc. Radiothermal radiation is theoretically provided by all physical bodies, whose temperature exceeds absolute zero $\left(-273.16^{\circ} \mathrm{C}\right)$. Detection of objects by means of radiothermal direction finding is carried out due to their contrast with the thermal radiation of the background, 
which is being monitored [6-9]. RTD means are weatherproof and stealthy. However, unheated objects are exposed to natural meteorological and artificial noise and interference.

The main disadvantages of RTD (as well as IR direction finding) include the lack of range resolution, the inability to identify well-conducting unheated and heated parts of objects.

Laser (optical) location is a set of methods for detecting, measuring coordinates and parameters, as well as recognizing the shape of distant objects using electromagnetic waves in the optical range - from ultraviolet to far infrared [9-13]. Laser location enables high-accuracy (up to several tens of $\mathrm{cm}$ ) mapping of the Earth's surface, the surface of the Moon, determination of the distance to space objects, airplanes, clouds, surface and underwater (using the green part of the spectrum) objects, studying the distribution of layers in the atmosphere. The main advantages of the optical locators over the radiolocators are greater accuracy in determining the angular coordinates of objects (by the maximum of the reflected signal) and high resolution in range [9].

In particular, when using a laser beam with a divergence angle of about 5', the error in determining the angular coordinates of the object is less than $0.4-0.5^{\prime}$ (for radars $-20-25^{\prime}$ ); with a light pulse duration of $2.5 \mathrm{~ns}$, the range resolution can reach several $\mathrm{cm}$. In addition, the laser locator has a high angular resolution, that is, the ability to identify two neighboring equidistant objects, which is due to the very high directivity of the laser radiation.

The high resolving power of the laser locator makes it possible in principle to solve the problem of recognizing the shape of objects even against the background of external natural or artificial interference and noise. A significant disadvantage of optical locators is their difficult use in difficult meteorological conditions (with snow, rain, fog, ice, etc.) for identifying objects at long ranges.

In practice, the creation of optical locators with a long range of action, high accuracy and resolution became possible only with the advent of such powerful sources of coherent radiation as optical quantum generators - lasers. Due to the quantum nature of the laser radiation interaction with receiver detector and laser radiation coherence signal processing methods in the optical locator are probabilistic (statistical). If LL determines only the distance to objects, it is often called a laser range finder.

Radiolocation. The main advantages of the radiolocation systems in comparison with the infrared systems (IRS) and RLS are the following capabilities [6-9]:

- the detection and recognition of several objects weakly radiating (or non-radiating) in the infrared and radio ranges;

- the ability of resolving a number of objects in range;

- application for recognizing a number of additional characteristics and parameters of objects studied against the background of external natural or artificial interference and noise.

A brief analysis of the multifunctional use of the considered systems for the detection and recognition of said objects shows the following.

1. The combination of IRD and RTD makes the complex of detection and recognition systems all-weather, allows to determine the parameters of low-temperature objects almost against a zero background. Such a complex will make it possible to additionally use (as signs of recognition) the intensity of thermal radio emission of objects, the polarization of the waves emitted by the object; the spectrum of fluctuations and the law of distribution of the amplitude 
of the signal in the radio range due to the movement of objects. It also will make it possible to measure the radial velocity of objects.

2. Combining the use of IRD and RLS also provides the application of the effective scattering area of objects (ESA), the number and ESA of "shiny" points of an object for recognition. (Some parts of objects, such as an airplane, reflect electromagnetic waves much more effectively than the others. In radars, such parts are called "shiny" dots by analogy with reflections from mirror parts.) In addition, polarization of waves and fluctuations in the signal reflected from moving objects can be used. The combined use of IRD and RLS can improve the quality of recognition by each of these tools. Thus, for example, using RLS for the detection of the fact that two objects are in the same angular direction with an indicative indication of their classes eliminates the uncertainty of the recognition of IRD and facilitates this process. In turn, when determining the angle of the object movement, the IRD increases the accuracy of recognition of objects by the number and parameters of the "shiny" points of the object, depending on the angle.

\section{Using a radar for the detection, recognition, extraction and measurement of parameters of the studied complex distorted images of objects based on their impulse characteristics}

The structures of complex objects against the background of external natural or deliberate interference and noise irradiated by electromagnetic fields can be considered to a certain extent as passive linear radio systems. Passive linear radio systems are quite fully characterized by a complex transmission coefficient, as well as two characteristics: the pulsed one, $h(t)$ and the transitional one, $g(t)$. These characteristics are uniquely related to each other by well-known analytical expressions. Therefore, it is often sufficient to determine only one of them and calculate the other from it. The difference in the impulse characteristics of objects can be used qualitatively for their identification and recognition. For RLS, it is practically more convenient to determine the impulse response of the object by studying the transitional one. A very important advantage of this recognition is the practical impossibility of interfering with the detection and recognition of objects against the background of external natural or deliberate interference and noise by applying radar absorbing materials to them due to the use of low-frequency spectrum signals by the locator.

The impulse characteristic $h(t)$ is the response of the research linear device to the input signal in the form of the delta function $\delta(t)$. It is known that physically the delta function is practically unrealizable. In practice, the impulse response $h(t)$ is determined using ultrashort pulses of duration and with a spectrum concentrated in a narrow frequency range from 0 to $f_{v}$, where $f_{v}$ is the upper boundary frequency determined by the type of the studied radio engineering system. Reflected radar signals of objects are mainly associated with the presence and action of "shiny" points that are formed by antennas, large surfaces of small curvature, surface joints, boundaries between materials with different electrical properties, sharp edges and corner reflectors. Therefore, the resolution of the RLS radio signals in range should be commensurate with the size of the "shiny" points. The number of shiny points in objects is usually small. Note that in many cases, the use of pulses providing a resolution in range of about 7-10 times less than the length of a recognized object in range $\Delta \mathrm{R}_{\mathrm{ob}}$ can provide for the detection and measurement of the parameters of "shiny" points of the research object against the background of external natural or artificial interference and noise. 
When RLS are emitted from standard rectangular UHF microwave pulses of duration $\tau_{i}$, resolving power along the RLS range against the background of external natural or artificial interference and noise is $\Delta R=c \tau / 2$ (c is the speed of light, $3 \times 10^{8} \mathrm{~m} / \mathrm{s}$ ).

Assuming that the range resolution is $\Delta R=0.1 R_{\mathrm{ob}}$, we find the required pulse duration of the RLS irradiating the object

$$
\tau_{i}=0.2 R_{\mathrm{ob}} / c .
$$

For simple pulsed signals, the effective duration $\tau_{e}$ and the spectrum width $\Delta f_{e}$ are interrelated by the ratio: $\Delta f_{e} \approx 1 / \tau_{e}$. In accordance with this formula, in order to determine the impulse response of an object under investigation $h(t)$, the radar must emit short impulse signals with an effective spectrum width from 0 to $f_{h} \approx 5 c / R_{\mathrm{ob}}$.

\section{Distortion of the emitted radio signal by receiving-transmitting antenna RLS}

Practical RLS antennas cannot emit and receive signals with a frequency spectrum from 0 to $f_{h}[1,4,9,13]$. Even ultra-wideband antennas can operate only in a certain frequency range from $f_{h}$ to $f_{l}$ satisfying the condition $\left(f_{h} / f_{l}\right) \leq 10$. Failure to pass the RLS antenna of the part of the frequency spectrum leads to distortion of the useful signal.

Figure 2 shows the signal with the missing low-frequency part of the spectrum with the ratio $\mathrm{K}=f_{h} / f_{l}=0.25$. The signal has a maximum side lobe level of $-0.475 \mathrm{~dB}$. A large level of lobes is unacceptable for object recognition.

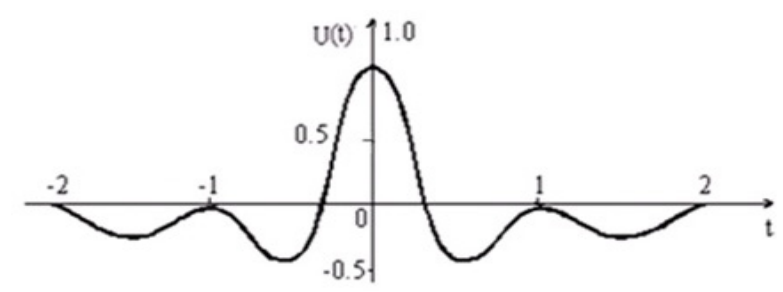

Fig. 2. Pulse signal with zero low-frequency part of the spectrum.

As studies show, methods of reducing side signals widely used in radiolocation and based on the use of weight functions - filters ("windows") are not effective in the case of signals with an absent low-frequency part of the spectrum. We illustrate this with the example of the socalled Hamming windows (filter). Introducing it must change the signal spectrum according to the law

$$
\begin{gathered}
U(t)=2 \int_{f_{l}}^{f_{h}} S_{0}\left(0.08+0.92 \cos \pi f /\left(2 f_{h}\right)\right) \cos 2 \pi f t d f= \\
(U / \pi)\left(0.54 / f_{h} t-0.23 /\left(f_{h} t-1\right)-0.23 /\left(f_{h} t+1\right)\right) \sin 2 \pi f_{h} t- \\
-(K U / \pi)\left(0.54 / K f_{h} t-0.23 /\left(K f_{h} t-1\right)-0.23 /\left(K f_{h} t+1\right)\right) \sin K 2 \pi f_{h} t .
\end{gathered}
$$

Figure 3 shows this signal for the coefficient $\mathrm{K}=0.2$.

For this signal, the maximum level of the side lobe is approximately equal to $-13 \mathrm{~dB}$, which is unacceptable when recognizing small objects against the background of external natural or artificial interference and noise. 


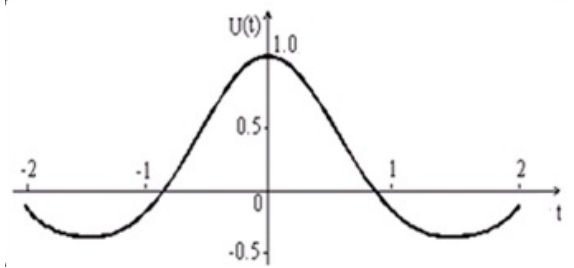

Fig. 3. Impulse with the missing low frequency part of the spectrum and the Hamming weight function.

\section{Conclusions}

1. We determined the advantages and disadvantages of detecting, recognizing, distinguishing borders and measuring various parameters of noisy, low-contrast, distorted images of objects using IRD, laser location and RLS. The data are often mismatched, which makes the joint use of these methods expedient. The joint use of IRD, LL and RLS for detection and recognition extends the classes of recognizable objects, increases the probability of their correct recognition due to the increased information content of existing recognitions owing to the joint measurement of object parameters by different means.

2. The possibility of recognizing objects in the image by their impulse characteristics is presented. A significant advantage of this recognition feature is the practical impossibility of counteracting recognition by applying radar absorbing materials to the surface of objects. The occurrence of pulse distortion by antennas that do not pass the low-frequency part of the pulse spectrum is noted. This disadvantage can be eliminated by introducing weighted signal processing and using the filtering properties of the quadrature detector. Expanding the range of frequencies used in the radar is possible due to the parallel operation of different-band antennas. In this case, it is possible to reduce the levels of the side lobes of the radar pulse without significantly reducing its duration.

\section{References:}

1. Zheleznova S.E., Milovanova N.V., Makeenkova N.S., Buzylev F.N., Mamaev O.Yu., Zatolokin S.A. Method and program for processing low-contrast images. In: Procc. of the VII International scientific and technical conference «Fundamental problems of Radioengineering and Device Construction», INTERMATIC - 2010, November 23-27, 2010; (3):254-256. (in Russ.).

2. Lebed'ko E.G., Porfir'ev L.F., Xaitun F.I. Teoriyairaschetimpul'snykhitsifrovykhoptiko-elektronnykh system (Theory and calculation of pulsed and digital optoelectronic systems). Leningrad: Mashinostroenie; 1984. 191 p. (in Russ.).

3. Matveev I.N., Protopopov V.V., Troitskii I.N., Ustinov N.D. Lazernaya lokatsiya (Laser location). N.D. Ustinov (Ed.) Moscow: Mashinostroenie; 1984. 272 p. (in Russ.).

4. Lobanov B.S., Sigov A.S., Milovanova N.V., Nefedov V.I., Kushnarev N.A., Popov E.A. Analysis detection and identification of ground and air targets. Naukoemkietekhnologii = Science Intensive Technologies. 2011;12(9):3-9 (in Russ.).

5. Nefedov V.I. Digital image processing. In: Radioelectronics and communications. Coll. Sci. works. Moscow: MIREA Publishing House; 2001. P. 119-133 (in Russ.).

6. Nikolaev A.G., Pertsev S.V. Radioteplolokatsiya (Radiolocation). Moscow: Voenizdat; 1970. 132 p. (in Russ.).

7. Nebabin V.G., Grishin V.K. Metody i tekhnika radiolokatsionnogo raspoznavaniya (Methods and techniques of radar recognition). Moscow: Radio isvyaz'; 1984. 152 p. (in Russ.).

8. Nefedov V.I., Trefilov D.N., Dementiev A.N., Vetrova V.V., Kolesnikov S.M., Shpak A.V. Integral equations for modeling cylindrical mirror antennas. Rossiiskii tekhnologicheskii zhurnal = Russ. Technolog. J. 2017;5(3):124-129 (in Russ.). https://doi.org/10.32362/2500-316X-2017-5-3-124-129

9. Lebed'ko E.G. Sistemy opticheskoi lokatsii, chast' 2, Uchebnoe posobie dlya VUZov (Optical location systems. V. 2. Textbook for Universities). St. Petersburg: ITMO Publishing House; 2012. 129 p. (in Russ.). 
10. Krylov V.I., Rukhadze A.A., Nefedov V.I. On a partial solution of the diffusion equation. Bulletin of the Lebedev Physics Institute. 2017;44(2):36-39. http://dx.doi.org/10.3103/S1068335617020038

11. Cook Ch., Bernfeld M. Radiolokatsionnye signaly. Teoriya i primenenie (Radar signals. Theory and application). V.S. Kelson (Ed.). Moscow: Sovetskoe radio; 1971. 567 p. (in Russ.).

12. Nefedov V.I., Sigov A.S. Obshhaja teorija svjazi (General communication theory). Moscow: Jurajt; 2019. 495 p. (in Russ.). ISBN 978-5-534-01326-9

13. Svistov V.M. Radiolokacionnye signaly i ih obrabotka (Radar signals and their processing). Moscow: Sovetskoe radio; 1977. 448 p. (in Russ.).

14. Bochkarev A.M., Dolgov I.M. Radar stealth aircraft. Zarubezhnaja radiojelektronika = Foreign Radioelectronics 1989;2:3-17 (in Russ.).

15. Benenson L.S. (Ed.). Sverhshirokopolosnye antenny (Ultra-wideband antennas). Moscow: Mir; 1964. 416 p. (in Russ.).

\section{Литература}

1. Железнова С.Е., Милованова Н.В., Макеенкова Н.С., Бузылев Ф.Н., Мамаева О.Ю., Затолокин С.А. Метод и программа обработки слабоконтрастных изображений. Материалы VIIМеждунар. научно-технической конференции «Фундаментальные проблемы радиоэлектронного приборостроения» INTERMATIC - 2010, 23 -27 ноября 2010;(3):254-256.

2. Лебедько Е.Г., Порфирьев Л.Ф., Хайтун Ф.И. Теория и расчет импульсных и цифровых оптико-электронных систем. Л.: Машиностроение, 1984. 191 с.

3. Матвеев И.Н., Протопопов В.В., Троицкий И.Н., Устинов Н.Д. Лазерная локация, под ред. Н.Д. Устинова. М.: Машиностроение, 1984. 272 с.

4. Лобанов Б.С., Сигов А.С., Милованова Н.В., Нефедов В.И., Кушнарев Н.А., Попов Е.А. Анализ методов обнаружения и распознавания наземных и воздушных объектов. Наукоемкие технологии. 2011;12(9):3-9.

5. Нефедов В.И., Сигов А.С. Цифровая обработка изображений. Радиоэлектроника и связь: Сб. научных трудов МИРЭА, 2001. С. 119-133.

6. Николаев А.Г., Перцев С.В. Радиотеплолокация. М.: Воениздат, 1970. 132 с.

7. Небабин В.Г., Гришин В.К. Методы и техника радиолокационного распознавания.М.: Радио и связь, 1984. 152 с.

8. Нефедов В.И., Трефилов Д.Н., Дементьев А.Н., Ветрова В.В., С.М. Колесников, Шпак А.В. Интегральные уравнения для моделирования цилиндрических зеркальных антенн. Российский технологический журнал. 2017;5(3):124-129. https://doi.org/10.32362/2500-316X-2017-5-3-124-129

9. Лебедько Е.Г. Системы оптической локации. Ч. 2: Учебное пособие для ВУЗов. СПб: НИУИТМО, 2012. 129 с.

10. Krylov V.I., Rukhadze A.A., Nefedov V.I. On a partial solution of the diffusion equation. Bulletin of the Lebedev Physics Institute. 2017;44(2):36-39. http://dx.doi.org/10.3103/S1068335617020038

11. Кук Ч., Бернфельд М. Радиолокационныесигналы. Теория и применение: пер. с англ., под ред. В.С. Кельзона. М.:Советское радио, 1971. 567 с.

12. Нефедов В.И., Сигов А.С. Общая теория связи. М.: Юрайт, 2019. 495 с.ISBN 978-5-534-01326-9

13. Свистов В.М. Радиолокационные сигналы и их обработка. М.: Советское радио, 1977. 448 с.

14. Бочкарев А.М., Долгов М.И. Радиолокация малозаметных летательных аппаратов. Зарубежная радиоэлектроника. 1989;2:3-17.

15. Сверхширокополосные антенны:пер. с англ.,под ред. Л.С. Бененсона. М.: Мир, 1964. 416 с.

\section{About the authors:}

Nguyen Minh Tuong, Postgraduate Student, Department of Telecommunications and Telecommunications, Institute of Radio Engineering and Telecommunication Systems, MIREA - Russian Technological University (78, Vernadskogo pr., Moscow 119454, Russia).E-mail: nguyenminhtuong31292@gmail.com

Viktor I. Nefedov, Dr. Sci. (Engineering), Professor, Head of the Department of Communication Systems and Telecommunications, Institute of Radio Engineering and Telecommunication Systems, MIREA - Russian Technological University (78, Vernadskogo pr., Moscow 119454, Russia). ORCID: 1234. DOI: 10.1134 / S0033849419020027.??? E-mail: nefedov@mirea.ru

Nikolay S. Chekalkin, Cand. Sci., Head of the Department of Mathematics-2 Physics and Technology Institute, MIREA - Russian Technological University (78, Vernadskogo pr., Moscow 119454, Russia). E-mail: chekalkin@mirea.ru

Igor V. Kozlovsky, Postgraduate Student of the Department of Communications and Telecommunications, Institute of Radio Engineering and Telecommunication Systems, MIREA - Russian Technological University (78, Vernadskogo pr., Moscow 119454, Russia).

Aleksey V. Malafeev, Postgraduate Student, Institute of Radio Engineering and Telecommunications, MIREA Russian Technological University (78, Vernadskogo pr., Moscow 119454, Russia). 
Natalia A. Mirolyubova, Senior Lecturer, Department of Foreign Languages, Institute of Radio Engineering and Telecommunications, MIREA - Russian Technological University (78, Vernadskogo pr., Moscow 119454, Russia). E-mail: mirolyubova@mirea.ru

Maksim A. Nazarenko, Cand. Sci., Assoc., Head of the Department of Quality Management and Certification, Institute of Radio Engineering and Telecommunication Systems, MIREA - Russian Technological University (78, Vernadskogo pr., Moscow 119454, Russia).

\section{Об авторах:}

Нгуен Минъ Тыюнг, аспирант кафедры Систем связи и телекоммуникаций Института радиотехнических и телекоммуникационных систем ФГБОУ ВО «МИРЭА - Российский технологический университет» (119454, Россия, Москва, пр-т Вернадского, д. 78). 8-965-166-76-65 E-mail: nguyenminhtuong31292@gmail.com.

Нефедов Виктор Иванович, доктор технических наук, профессор, заведующий кафедрой Систем связи и телекоммуникаций Института радиотехнических и телекоммуникационных систем ФГБОУ ВО «МИРЭА - Российский технологический университет» (119454, Россия, Москва, пр-т Вернадского, д. 78). ORCID: 1234. DOI: 10.1134/S0033849419020027.8-909-964-03-20,E-mail: nefedov@mirea.ru.

Чекалкин Николай Степанович, кандидат технических наук, заведующий кафедрой Математики-2 Физико-технологического института ФГБОУ ВО «МИРЭА - Российский технологический университет» $(119454$, Россия, Москва, пр-т Вернадского, д. 78). 8-965-166-76-65/ E-mail: chekalkin@mirea.ru.

Козловский Игорь Валеръевич, аспирант кафедры Систем связи и телекоммуникаций Института радиотехнических и телекоммуникационных систем ФГБОУ ВО «МИРЭА - Российский технологический университет» (119454, Россия, Москва, пр-т Вернадского, д. 78).

Малафеев Алексей Викторович, аспирант кафедры Систем связи и телекоммуникаций Института радиотехнических и телекоммуникационных систем ФГБОУ ВО «МИРЭА - Российский технологический университет» (119454, Россия, Москва, пр-т Вернадского, д. 78).

Миролюбова Наталья Алексеевна, доцент кафедры иностранных языков Института радиотехники и телекоммуникаций, ФГБОУ ВО «МИРЭА - Российский технологический университет» (пр. Вернадского, 78, Москва, 119454, Россия). 8-905-733-28-61, mirolyubova@mirea.ru.

Назаренко Максим Анатольевич, кандидат технических наук, доцент, заведующий кафедрой Управления качеством и сертификации Института радиотехнических и телекоммуникационных систем ФГБОУ ВО «МИРЭА - Российский технологический университет» (119454, Россия, Москва, пр-т Вернадского, д. 78). 